УДК 37.013.77 (045)

DOI:

Юрій Костюшко, кандидат педагогічних наук, доиент кафедри дошкільної педагогіки Житомирського державного університету імені Івана Франка

Наталія Сейко, доктор педагогічних наук, професор кафедри соціальних технологій Житомирського державного університету імені Івана Франка

\title{
КОНФЛІКТИ В ПЕДАГОГІЧНОМУ ПРОЦЕСІ ТА КОМПЕТЕНТНІСНІ ЗАСАДИ ЇХ ВИРІШЕННЯ
}

У статті з'ясовано зміст та специфіку професійної компетентності вчителя у розв 'язанні конфліктів з учнями в педагогічному процесі. Обтрунтовано думку про необхідність формування конфліктологічноі компетентності педагога. Доведено, що в ситуачії педагогічного конфлікту шлях до інтеграчії лежить через примирення, щуо передбачає реалізацію співробітництва учасників конфлікту. Сформульовано висновок, що метою примирення учасників конфлікту в педагогічному процесі є зміна взаємовідносин між учасниками конфлікту.

Ключові слова: професійна компетентність; педагогічний процес; конфлікт; іниидент; ситуація конфлікту.

Jim. 9.

Yuriy Kostiushko, Ph.D.(Pedagogy), Associate Professor of the Preschool Education and Pedagogical Innovations Department Zhytomyr Ivan Franko State University

Natalia Seiko, Doctor of Sciences (Pedagogy), Professor of the Social Technologies Department Zhytomyr Ivan Franko State University

\section{CONFLICTS IN THE PEDAGOGICAL PROCESS AND COMPETENCE FOUNDATIONS OF THEIR RESOLUTION}

The research clarifies the content and specifics of the teachers' professional competence for resolving conflicts in student classroom. The idea of the necessity to form the teachers' conflict competence, which combines communicative, reflective, evaluative, regulatory competences and the competence of dynamism as part of the teachers' professional competence is substantiated. In this research conflict competence is defined as an attribute of the personal level, a system of acquired ways which help an individual to act productively in a conflict situation and resolve it constructively. The essence of the concepts "conflict", "situation of the conflict", "conflict situation" is outlined. It is determined that during the conflict in the pedagogical process distancing is characterized by the fact that opponents emphasize the differences between them on the psychological (temperament, character traits, dominant mental processes) (especially the level of development of cognitive mental processes), the dominance of certain negative states, destructive behavioral patterns, etc.), social (education, clothing style, social norms, attitudes, beliefs, interests, hobbies, social status, social roles, system of personal attitudes to the life, physical aspect (height, weight, complexion, etc.) or mental (imagination, self-suggestion, self-belief, internal attitudes, inner desire for selfimprovement, self-knowledge, knowledge of reality, beauty and harmony, the desire for well-being, to comprehend reality, the search for goals and sense of human existence) levels. The main characteristics of the conflict situation in the pedagogical process and the danger of its escalation into an incident are presented. It is determined that in the situation of pedagogical conflict the way to integration passes through reconciliation, which involves the implementation of cooperation between the participants of the conflict. The conclusion that the aim of reconciliation of the participants of the conflict in the pedagogical process is to change the relationship between them, which arises as a result of the implementation of internal work by both the teacher and the pupil is formulated.

Keywords: professional competence; pedagogical process; conflicts; conflict situation.

П остановка проблеми. Трансформаційні процеси у вітчизняній системі освіти торкнулися не лише суто організаційних та змістових засад іiі функціонування, а й наповнення суб'єкт-суб'єктних відносин у педагогічному процесі. На значущості ефективної міжособистісної взаємодії педагога з учнями наголошують основні вітчизняні документи про освіту, насамперед,
Закон України “Про освіту” (2017), який визначає компетентнісні засади професійної діяльності вчителя у закладі загальної середньої освіти як “динамічну комбінацію знань, умінь, навичок, способів мислення, поглядів, цінностей, інших особистих якостей, що визначає здатність особи успішно соціалізуватися, провадити професійну та/ або подальшу навчальну діяльність" [9]. 


\section{КОНФЛІКТИ В ПЕДАГОГІЧНОМУ ПРОЦЕСІ ТА КОМПЕТЕНТНІСНІ ЗАСАДИ ЇХ ВИРІШЕННЯ}

У змісті професійної компетентності педагога важливе значення має його здатність розпізнавати й урегульовувати конфлікти, та ефективно впливати на міжособистісну взаємодію у процесі конфлікту. Конфлікти в педагогічному процесі явище неминуче. Володіння вчителями конструктивними стратегіями міжособистісної взаємодії у ситуації конфлікту виступає однією 3 найважливіших складових їхньої професійної компетентності.

Стан дослідженості проблеми. У сучасному науковому просторі ті чи ті аспекти компетентності у різних сферах професійної діяльності досліджували І. Зимняя, А. Деркач, Н. Кузьміна, О. Дубасенюк, І. Зязюн, С. Лейко, М. Леонт'єв, О. Марущак, Л. Мітіна, В. Семиченко, А. Реан та ін. Зокрема проблему конфліктологічної компетентності педагога розглядали А. Анцупов, Е. Богданов, М. Кашапов, А. Куликов, Л. Петровська, Б. Хасан, Л. Цой, А. Шипілов та ін. Водночас поза увагою науковців залишилися питання аналізу конфліктологічної компетентності вчителя та його здатності налагоджувати ефективні стратегії міжособистісної взаємодії у конфліктних ситуаціях у педагогічному процесі.

У зв'язку з цим мета статті - 3'ясувати зміст та специфіку професійної компетентності вчителя у розв'язанні конфліктів з учнями в педагогічному процесі.

Виклад основного матеріалу. Науковці надають різного тлумачення поняттю “компетентність”, а саме: сукупність компетенцій; знаючий, поінформований, авторитетний в якійсь галузі; “здатність до дії” як уміння використовувати знання у практичній діяльності, як певні стратегії для реалізації творчого потенціалу особистості; рефлексія власних дій; рівень обізнаності про діапазон можливих стратегій взаємодії і вміння адекватно реалізувати ці стратегії у конкретній життєвій ситуації; якість особистості, її певне надбання, що грунтується на знаннях, досвіді, моральних засадах i проявляється в критичний момент за рахунок вміння знаходити зв'язок між ситуацією та знаннями у прийнятті адекватних рішень нагальної проблеми; результат набуття компетенцій; готовність до виконання поставленої задачі, яке включає в своє поняття елементи особистісних характеристик людини (гнучкість, ініціативність, мобільність тощо); перехід від якості знання до якості діяльності; складова професіоналізму; актуальна особистісна якість, що базується на знаннях; загальна здатність, заснована на знаннях, уміннях та цінностях; наявність знань, досвіду і навичок, необхідних для ефективної діяльності; якість людини, яка володіє глибокими знаннями в якій-небудь галузі і думка якої є вагомою, авторитетною; знання, вміння і досвід власної діяльності, які дають змогу виносити авторитетні судження і приймати правильні рішення.

Компетентний - це (від лат. Competens підходящий, відповідний, узгоджений) - це той, хто має достатні знання в якій-небудь галузі, який $з$ чим-небудь добре обізнаний, тямущий [7, 250]. Л. Ярослав (2009) здійснив аналіз сутності, структури, закономірностей функціонування та розвитку конфліктологічної компетентності різних фахівців, провівши порівняльний аналіз цього виду компетентності 3 такими поняттями, як “конфліктна компетентність”, “конфліктологічна компетенція", “конфліктологічна грамотність”, “конфліктологічна підготовка" [4]. Оскільки розвиток конфліктологічної компетентності вчителя тісно пов'язаний з його комунікативними здібностями, звертає на себе увагу дослідження Л. Бірюк та С. Пішуна (2021) про парадигмальні засади формування вмінь і навичок ефективної комунікації, в тому числі у ситуації конфлікту [1]. Актуальним для нашого дослідження компетентності є визначення, запропоноване В. Семиченко (1997) [6]. Отже, конфліктологічна компетентність - це атрибут особистісного рівня, система засвоєних способів, за допомогою яких суб'єкт продуктивно діє у ситуації конфлікту та конструктивно ii вирішує. Конфліктологічна грамотність, навички у розв'язуванні суперечок, життєвий досвід стають дієвими відповідно до мети врегулювання конфліктів, інтегруючись у цю спільну систему способів.

Оскільки ми розглядаємо поняття конфліктологічної компетентності, то маємо визначитися з відповідним тлумаченням поняття “конфлікт”. Усі наявні в науковій літературі визначення, на нашу думку, можна поділити на дві групи: перша з них містить поняття “протиріччя”, натомість друга “зіткнення” [7]. Конфлікт (від лат. conflictus) ми будемо розглядати як зіткнення несумісних психологічних, соціальних, духовних сил (аспектів), яке викликає протидію. Традиційно у вітчизняній та зарубіжній конфліктології виділяють такі стадії розвитку конфлікту: 1) виникнення об'єктивної конфліктної ситуації; 2) усвідомлення об'єктивної конфліктної ситуації; 3 ) інцидент; 4) ескалація; 5) кульмінація; 6) завершення конфлікту. Конфліктна ситуація - це прихований потенційний конфлікт, який може перерости у відкритий або існувати у латентній формі.

3'ясуємо відмінність між поняттями “конфліктна ситуація" та "ситуація конфлікту”. Більшість науковців, які досліджують проблеми 


\section{КОНФЛІКТИ В ПЕДАГОГІЧНОМУ ПРОЦЕСІ ТА КОМПЕТЕНТНІСНІ ЗАСАДИ ЇХ ВИРІШЕННЯ}

конфліктів, визначають конфліктну ситуацію як основу конфлікту, що передує йому, фіксуючи об'єкт конфлікту й реальні суперечливі позиції, цілі та засоби їх досягнення, інтереси, бажання, потяги суб'єктів потенційного конфлікту. “Ситуація конфлікту”, на нашу думку, - дещо ширше поняття, ніж “конфліктна ситуація" і, власне, саме поняття "конфлікт".

Для конфліктної ситуації характерним $є$ : прагнення заручитись підтримкою своїх прихильників (однодумців); турбота про збереження свого іміджу та самооцінки; підготовка до відкритої протидії (зіткнення). На цьому етапі для педагога важливо є надати дитині можливість висловити (чи виявити іншим способом) свої почуття; можливість “охолонути” та заспокоїтись; обрати стратегію поведінки, яка буде прийнята дитиною; творчо досліджувати всі можливості конструктивного розв'язання проблеми.

Педагог може організовувати бесідупримирення (переговори) або “переговори про наступні переговори”, але проблема не дається за рахунок негативного фону (емоції, почуття, думки) i, як наслідок, контакти мінімізуються або ж виникає інцидент. У такому разі взаємодія набуває формальної, напруженої форми, проблема переходить у латентну фазу (форму). Інцидент це перше відкрите зіткнення, яке переходить у конфліктну взаємодію. Така взаємодія має характерні особливості: вона завжди руйнівна; знищує духовні цінності; зміст такого роду взаємодії реалізується на паралелі “дія протидія"; учасники інциденту зосереджені на досягненні особистісного успіху, перемозі будьякою ціною. Негативні першопричини дій вчителя, які викликають інцидент (конфліктну взаємодію) в учнівському середовищі, можна окреслити так: негативна стереотипна реакція на дії учня (дитини); спішні пошуки врегулювання конфлікту під впливом афекту (зазначимо, що дії, вчинені в стані афекту, потім неможливо виправити, - особливо, якщо йдеться про педагогічну діяльність); прийняття неконструктивного рішення без осмислення ситуації (адже що більш коректно педагог осмислює ситуацію, то краще зможе на неї відреагувати); помилки в оцінюванні значення проблеми міжособистісної взаємодії; недоліки в аналітичному опрацюванні ситуації конфлікту; нестача цільової установки (існує необхідність врахувати довготривалий та короткотривалий вплив власної поведінки); розгубленість педагога перед потребою визначення альтернатив; недостатнє врахування наслідків дій у ході міжособистісної взаємодії; хибна самооцінка (помилкове сприйняття успіху).

Будь-який індивід у процесі міжособистісної взаємодії реалізує одну із стратегій - інтегрування або дистанціювання. Інтегрування передбачає співробітництво, співпрацю, співтворчість, повагу до інших людей, визнання іншої людини як цінності. Дистанціювання стоїть в одному синонімічному ряду 3 такими поняттями, як “віддалення”, “розмежування”, “розділення”. Для дистанціювання характерним $\epsilon$ те, що опоненти підкреслюють відмінності між ними на психологічному, соціальному чи духовному рівнях.

У процесі дистанціювання опоненти прагнуть досягнути свого, не враховуючи негативну реакцію партнера та наслідки для їх взаємовідносин, але можливий варіант, коли зусилля однієї зі сторін конфлікту можуть визначатися прагненням до збереження добрих відносин. Для ситуації конфлікту складність зумовлена такими чинниками, як-от: невизначеність вихідних даних (суперечливість, хибність даних про ситуацію; неусвідомленість предмета (об'єкта) зіткнення; негативні емоції (страх, гнів, недовіра, смуток тощо).

На відміну від інших сфер (політики, виробництва, бізнесу тощо), під час ситуації конфлікту результат у педагогічному процесі наперед визначений - це повне розв'язання проблеми, ліквідація іiі джерел. За інших умов (роз'єднання суб'єктів протидії або придушення однієї із сторін) конфлікт набуває інших форм чи переходить у латентну фазу і з часом може загостритися. Для того, щоб урегулювати конфлікт, необхідно зняти предмет дистанціювання, тобто те відношення, яке призвело до виникнення конфліктної ситуації. Інакше кажучи, суб'єкти конфлікту мають щось змінити в собі.

Ми не погоджуємося з думкою С. Болтівця, який стверджує: “'Звернення до ідей загальнолюдських цінностей на практиці є універсалізацією людини, позбавленням іїі індивідуальної неповторності, що дає підставу з “центру”, з позиції “супермена”, надлюдини накинути свій зміст пї діяльності і життя. Тому категорія загальнолюдського в людській природі може стосуватись здебільшого найпростіших відправлень іiі життєдіяльності, більшою мірою наближаючись до базальних психічних функцій і фізіологічних процесів" [2, 141]. Рух до оволодіння кращими морально-етичними взірцями людства у жодному разі не заперечує стану рівноваги в родинно-суспільному гомеостазі. Гомеостаз як стан рівноваги системи “в процесі свого індивідуального розвитку 


\section{КОНФЛІКТИ В ПЕДАГОГІЧНОМУ ПРОЦЕСІ ТА КОМПЕТЕНТНІСНІ ЗАСАДИ ЇХ ВИРІШЕННЯ}

проходить послідовні етапи ускладнення, диференціації, трансформації своєї структури" [5, 364].

У ситуації педагогічного конфлікту шлях до інтеграції лежить через примирення, що передбачає реалізацію співробітництва та визнання власної неправоти. Таким чином, маємо схему подолання конфлікту в педагогічному середовищі: дистанціювання $\rightarrow$ примирення (через особистісні зміни опонентів) $\rightarrow$ інтеграція (налагодження конструктивних взаємовідносин). У реалізації наведеної вище схеми важливо враховувати почуття, які супроводжують конфлікт (гнів, образу, підозра); вважаємо, що саме почуття (суб'єктивні моменти) “підривають” наші взаємини, і навіть після врегулювання об'єктивних суперечностей у конфлікті такі почуття не зникають, тому завжди існує небезпека виникнення нового конфлікту, у зв'язку з чим реалізується ланцюжок подій: негативні почуття заважають врегулюванню конфлікту педагога 3 дитиною, яке має розпочинатися з визнання того, що він не має рації; педагог має донести розуміння дитині, що вона також поміняється; вважає педагог, що має рацію чи не має, саме він має зробити перший крок до примирення; організовуючи контакт, педагог відкривається дитині - в цьому є певна небезпека порушення соціально-статусної рівноваги в педагогічному конфлікті.

Метою примирення виступає повна зміна взаємовідносин - від дисгармонії до гармонії, від конфлікту до мирного співіснування, від ненависті до любові. Учасники конфлікту в педагогічному процесі не можуть примиритись один з одним, допоки не наступає примирення з собою, тобто не відбудеться відповідна внутрішня робота над собою. Найпростіше примиритись у ситуації конфлікту між педагогом та учнем під час особистої зустрічі віч-на-віч. Для цьього з боку педагога необхідно: взяти ініціативу в свої руки; розповісти про свої відчуття, зізнатися у своїх проблемах; втримати проблему в певних межах, визнати їі наявність, швидко діяти для ії вирішення. Для вчителя в процесі зустрічі-примирення важливо: володіти більш детальною інформацією, вміти активно слухати, вміти оцінювати почуття дитини, швидко думати та адекватно реагувати, бути наполегливим. Зустріч заради примирення передбачає, що: прагнення залагодження конфлікту є взаємним; найбільш активно діє ображена сторона; все має відбуватися без попередніх умов; вчитель має готовність прийняти та пробачити; примирення відбувається не на пустому місці, а в результаті певної підготовки.
Урегулюванню конфлікту - це розв'язання не лише проблеми, пов'язаної з несумісними позиціями сторін на психологічному, соціальному чи духовному рівнях, але й пов'язаними з цим особистісними змінами. Конфлікт в такому разі перестає бути проблемою, а стає можливістю переосмислення “особистої історії. Рішення працювати над собою, змінювати особистісні характеристики може з'явитись у дитини у разі відчуття нею зрілої доброзичливості, безумовного прийняття з боку інших людей, передусім, батьків, педагогів. Стратегія поведінки педагога в ході урегулюванню конфлікту має бути ясною, простою й прямою, без подвійних смислів та недомовок; при цьому важливо постійно закріплювати позитивний досвід на шляху до примирення. За таких умов ризик неподоланності конфлікту в педагогічному процесі через нерозуміння дитиною поточної ситуації, невдач в прогнозуванні, плануванні та контактах буде зведений до мінімуму [9].

Для врегулювання конфлікту в педагогічному процесі треба враховувати дію таких факторів:

1. Прагнення двох сторін до примирення.

2. Рівність сил, що можливо лише за умови функціонування гуманістичної педагогічної системи. У гуманістичних педагогічних системах домінує фактор наявності суб'єкт-суб'єктних відносин між педагогом та дитиною, тобто рівність особистісних та статусних позицій. За інших умов всі конфлікти завершуються на користь дорослих учасників, тобто педагогів, якщо йдеться про конфлікт у педагогічному процесі.

3. Вдалий час та корисна напруга: педагог сам має бути готовим до примирення та бачити таку готовність у дитини; якщо дитина дуже розслаблена, або перебуває у стані стресу чи негативних емоцій, то у неї, напевно, не буде вистачати внутрішнього ресурсу шукати примирення.

4. Двоєдиність у процесі примирення двох фаз: диференціації та інтеграції. На першому етапі педагог намагається сам та допомагає дитині чіткіше уявити, що їх роз'єднує. Бажано створити схему, на якій наочно буде відтворено, що віддаляє учасників конфлікту один від одного, а що об'єднує. Далі розпочинається процес пошуку точок зближення та спільних цілей. Наступає фаза інтеграції. Педагог має максимально демонструвати свою щирість, відкритість і підтримку дитини, та закріплювати спільні конструктивні точки зору.

5. Атмосфера підтримки. Педагог передусім має бути повністю відкритим у стосунках 3 дитиною (відкритість передбачає автентичність та чуйність. Перш ніж організувати контакт, необхідно прийняти погляди та почуття дитини, 
навіть якщо педагог не погоджується з їх змістом і сутністю. Суттєвою перешкодою на шляху до конструктивної взаємодії в ситуації конфлікту між вчителем та учнем є т.зв. “слуховий бар'єр” (коли кожен з учасників конфлікту чує лише те, що хоче почути). Реалізуючи підтримку дитини в ситуації конфлікту, педагог має допомогти дитині зрозуміти витоки проблеми, що спричинила конфлікт, а також залучити (по можливості) своїх колег та батьків для підтримки дитини у процесі примирення.

Висновки. Отже, нами 3'ясовано зміст та специфіку розвитку професійної компетентності вчителя у врегулюванні конфліктів з учнями в педагогічному процесі. Обгрунтовано думку про існування особливої конфліктологічної компетентності педагога, яка об“єднує комунікативну, рефлексивну, оцінювальну, регулятивну компетенції, та компетенцію динамізму в складі професійної компетентності педагога. Сформульовано думку про те, що метою примирення учасників конфлікту в педагогічному процесі є зміна взаємовідносин між ними, що виникає внаслідок реалізації внутрішньої роботи над собою і з боку педагога, і з боку учня. Перспективи подальших наукових розвідок полягають у розробці та експериментальному підтвердженні моделі подолання конфліктів у педагогічному процесі.

\section{ЛІТЕРАТУРА}

1. Бірюк Л., Пішун С. Парадигмальний підхід у формуванні комунікативної компетентності майбутніх фахівців початкової школи. Молодь $i$ ринок. 2021. № 1(187). С. 22-27.

2. Болтівець С.І. Педагогічні ідеали психічної самоорганізації особистості. Психологопедагогічні засади розвитку особистості в освітньому просторі. Київ, 2008. С.139-151.

3. Закон України "Про освіту" Відомості Верховної Ради (ВВР), 2017, № 38-39, ст.380. URL: https://zakon.rada.gov.ua/laws/show/214519\#Text (дата звернення: 20.04.2021).

4. Костюшко Ю.О. Засади недирективної педагогіки як необхідна умова розв'язування міжособистісних конфліктів між учителем та учнями. Вісник Житомирського державного університету імені Івана Франка. Житомир, 2000. Вип.6. С.249-251.

5. Психология. Словарь. (Ред. А.Петровский, М.Ярошевский). Москва, 1990. 494 с.

6. Семиченко В.А. Пути повышения эффективности изучения психологии. Монография. Киев, 1997. 124 с.

7. Словник української мови: в 11т. АН УРСР. T.4. Київ: Наукова думка, 1973.840 с.
8. Словник-довідник термінів з конфліктології (Ред. М.Пірен, Г.Ложкін). Чернівці-Київ, 1995. 332 с.

9. Ярослав Л.О. Конфліктологічна компетентність як предмет психологічного дослідження. Вісник НТТУ “КПI”. Київ, 2009. №1 (25). С.116-119.

\section{REFERENCES}

1. Biriuk, L. \& Pishun, S. (2021). Paradyhmalnyi pidkhid u formuvanni komunikatyvnoi kompetentnosti maibutnikh fakhivtsiv pochatkovoi shkoly [A paradigmatic approach in the formation of communicative competence of future primary school professionals]. Youth \& market. No. 1(187). pp. 22 27. [in Ukrainian].

2. Boltivets, S.I. (2008). Pedahohichni idealy psykhichnoi samoorhanizatsii osobystosti [Pedagogical ideals of mental self-organization of the individual]. Psychological and Pedagogical Principles of Personality Development in the Educational Space. Kyiv, pp.139-151. [in Ukrainian].

3. Zakon Ukrainy "Pro osvitu". Vidomosti Verkhovnoi Rady (2017). [Law of Ukraine "On Education" Information of the Verkhovna Rada (VVR)]. No. 38-39, art.380. Available at: https:// zakon.rada.gov.ua/laws/show/2145-19\#Text (Accessed 20 Apr. 2021) [in Ukrainian].

4. Kostiushko, Yu.O. (2000). Zasady nedyrektyvnoi pedahohiky yak neobkhidna umova rozviazuvannia mizhosobystisnykh konfliktiv mizh uchytelem ta uchniamy [Principles of non-directive pedagogy as a necessary condition for resolving interpersonal conflicts between teacher and students].Zhytomyr Ivan Franko State University Journal. Zhytomyr, Vol.6. pp.249-251.[in Ukrainian].

5.Psykholohyia. Slovar. (1990). [Psychology. Dictionary]. (Ed.). A.Petrovskyi, M.Iaroshevskyi. Moscov, 494 p. [in Russian].

6.Semychenko, V.A. (1997). Puty povyshenyia effektyvnosty izuchenyia psykholohyy [Ways to Improve the Effectiveness of Studying Psychology]. Monograf. Kyiv, 124 p. [in Russian].

7.Slovnyk ukrainskoi movy (1973). [The Dictionary of the Ukrainian language]. Vol.4. Kyiv, 840 p. [in Ukrainian].

8.Slovnyk-dovidnyk terminiv z konfliktolohii (1995). [The Reference Dictionary of Terms in Conflictology]. (Ed.). M.Piren, H.Lozhkin. Chernivtsi-Kyiv, 332 p. [in Ukrainian].

9.Iaroslav, L.O. (2009). Konfliktolohichna kompetentnist yak predmet psykholohichnoho doslidzhennia [National Technical University of Ukraine]. “Kyiv Polytechnic Institute” Journal. Kyiv, no.1 (25). pp.116-119. [in Ukrainian].

Стаття надійшла до редакції 22.06.2021 